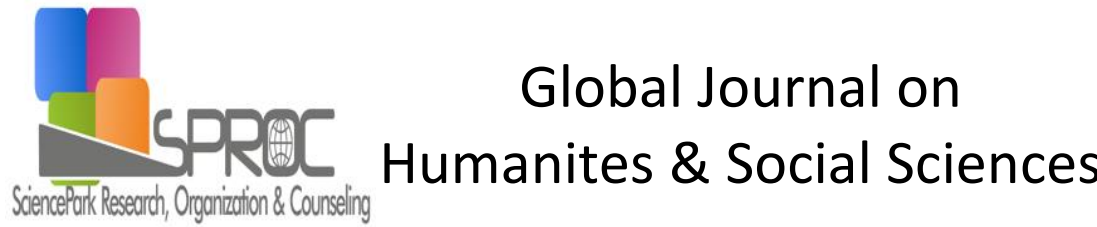

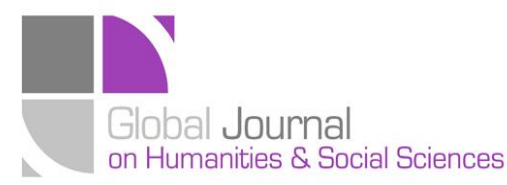

Vol 3 (2016) 149-156

Selected Paper of 4th World Conference on Design and Arts, (DAE-2015)

26-28 June 2015, St.Petersburg Christan University, St. Petersburg, Russia.

\section{Opinions of Vicente Blasco Ibanez, one of Travelers of $20^{\text {th }}$ Century about Clothes of Turks (Example of "Orient Before The Storm")}

Meyrem Arga Sahinoglu*, Department of Fashion Design, Faculty of Art and Design, Gazi University, Golbasi, Ankara, Turkey

\section{Suggested Citation:}

Arga Sahinoglu, M. (2016) Opinions of Vicente Blasco Ibanez, one of Travelers of $20^{\text {th }}$ Century about Clothes of Turks (Example of "Orient Before The Storm"),

$O$

03, pp 149-156. Available from: http://sproc.org/ojs/index.php/pntsbs

[Online].

Received Deceember 27, 2014; revised March 18, 2015; accepted April 01, 2015.

Selection and peer review under responsibility of Prof. Dr. Milan Matijevic.

C2016 SciencePark Research, Organization \& Counseling. All rights reserved.

\begin{abstract}
or

which are one of the oldest types of literature are the works of travelers who traveled different regions for different reasons and transfer the lives, cultures of the people where they travelled to the next generations.

Starting point of the author in itineraries is "geography" rather than events. Depending on this fact, the subject of an itinerary is the climate of the region, historical works, old-new buildings, clothes, details of the daily life etc. It is possible to assess itineraries as documents supporting historical, geographical and sociology sciences in terms of contents

The purpose of this research is to determine the opinions of $20^{\text {th }}$ century travelers on the clothes of Turks. In the research the itinerary of Vicente Blasco Ibanez named "Orient Before the Storm" was examined and it was tried to determine the opinions of the author about garments of that era. In "Orient Before the Storm" which is the travel notes of the Spanish traveler who came to Istanbul in August 1907, Vicente Blasco Ibanez, the great man of letters who is one of the leading politicians of his country states that what was told about Turks in Europe were not correct and wrote his detections which are remarkable even today. In the itinerary there are significant clues on clothing of Turks. Vicente Blasco Ibanez states in his itinerary that Ottoman garments were smart and magnificent.
\end{abstract}

Keywords: travel book, ottoman dress.

* ADDRESS FOR CORRESPONDENCE: Meyrem, Arga Sahinoglu, Department of Fashion Design, Faculty of Art and Design, Gazi University, Golbasi, Ankara and 06830, Turkey. : $\underline{\text { marga@gazi.edu.tr }}$ 
Arga Sahinoglu, M. (2016) Opinions of Vicente Blasco Ibanez, one of Travelers of $20^{\text {th }}$ Century about Clothes of Turks (Example of "Orient Before The Storm"), $\quad 0$

http://sproc.org/ojs/index.php/pntsbs

[Online]. 03, pp 149-156. Available from:

\section{Introduction}

Human beings wonder new places and the people living in new places and way of livings compliant to the definition of foreign by its very nature. This curiosity brings people into seeking ways that will reach outsiders and then make it known and defined. The texts fulfilling the necessity of human beings to see and define identify new places and having literary and historical characteristics are called as itinerary or travel writings. Traveler or itinerant tries to portray way of living of a community as a whole, traditions and customs and other topics that draws his/her attention in every respect and s/he assumes that it would draw the attention of reader in these works (Gokyay, 1973). Itineraries have historic features by reflecting the social, economic and educational specifications of that time of the geography to where the travel is taken (and even geographical with scenery descriptions partly) and literary features by author's telling the material and nonmaterial characteristics of the new places gingerly and original aspects of their livings in plain and warm language (Maden,2008).

Itineraries have informative characteristics. The author gives information to his readers about the places wandered and seen. Author write these texts up within the desire of telling the geographical, historical and social values of the new places s/he wandered and saw to his/her public (Maden,2008).

Another function of itineraries is its providing society a chance to see how it is perceived by others. Formation of itself and knowing how it is seen by others is significant for the societies as well as individuals (Donmez, 2013).

Despite all negative and positives opinions regarding itineraries, the fact that there were not too many written sources in the West concerning Ottomans in those periods has made itineraries important sources. In XIX and XX centuries, itineraries had a substantial role in identification of different cultures and various social lives. Travelers' impressions that are subjective to a large extent contributed to the society they lived in in terms of recognition of the 'other' (Akkanat, 2009). However, it shall not be forgotten that the writings may not always reflect the realities because of bias and negative thoughts of the ones writing itineraries (Mumcu, 1987).

The interest and curiosity of European travelers towards Turks dates back to old periods. Having a journey to eastern world, especially to Ottoman lands, traveler became mostly efficient in the generation of the image of "Turks" in western culture. For this reason, itineraries are essential resources in the researches directed on Turkish image in Europe.

The accuracy of the information that itinerants transferred to their societies, is mostly accepted and images related to each society perceived emerged. The image of Turks perceived by West is negative both because of its generally being referred with wars and cultural and belief differences. This case paved the way for emergence of the orientalist world-view which West "insults" and "excludes" the east it perceives as "other" with an European centered point of view (Akman, 2011).

This research analyzes the opinions of clothing in that period by studying the itinerary of Vicente Blasco Ibanez, one of the itinerants of XX. century called as "Orient Before Storm". In Orient Before Storm, being travel note of Spanish traveler coming to İstanbul in August 1907, great man of letters, Vicente Blasco Ibanez, being one of the leading politicians in his country stated that the things told in Europe about Turks were not correct.

\section{Method}

In this research, the itinerary of Vicente Blasco Ibanez, one of the itinerants of XX. century, called as Orient Before Storm were analyzed and his opinions on the clothing of that period were tried to be determined. The essential factor in selection of this itinerary is Vicente Blasco Ibanez's being a great man of letters and primary politicians in his country. 
Arga Sahinoglu, M. (2016) Opinions of Vicente Blasco Ibanez, one of Travelers of $20^{\text {th }}$ Century about Clothes of Turks (Example of "Orient Before The Storm"), $\quad 0$

http://sproc.org/ojs/index.php/pntsbs

[Online]. 03, pp 149-156. Available from:

Text-based examination method is based on in this research. Text-based examination method is the method of analysis, criticizing, making it understandable from itself and evaluation method starting from the work to be analyzed (Best, 1982).

\title{
3. Findings
}

Ottoman Empire contained a variety of nations in itself due to the cosmopolite structure it had and provided the opportunity for the protection of different cultures maintaining its existence within the same structure thanks to its understanding of tolerance it obtained as philosophy for the sake of providing peace. Armenian, Rum, Jewish and Turkish people living together continued their social lives with the images coming from their pasts and they accepted that they are differentiated from each other with their different appearances as well as different characters (ilya\& Uysal,2015). This diversity in cloths also attracted the attention of Vicente Blasco Ibanez.

\begin{abstract}
"The diversity of the cloths reminding a carnival surprises and dazzles people (Ibanez,2006)"

"Various kinds of crowd of İstanbul and nineteen nations different from each other and still protecting their customs and traditional cloths. Arabs coming from far Yemen provinces or Moors of Tripoli with the gray coats on their back and ropes made of camel hair knotted in their forehead passes; red-blue cloths of Croatians working as tipstaff in the houses of the rich people of İstanbul are ornamented with gallons and engravings entirely, a small and round barret in their heads with moustache, big Eibar pistol in large fabrics; Albanians and Macedonians with their short pleated skirts on their eastern costumes; Jews wear leather coats on their stripe holiday tunics despite the season is summer; Armenians with handkerchiefs wrapped around their berets; Rums easily recognized from their coal black eyes and pale skins resemble to olive color despite their European dressings; numberless men of god, imams, blind followers, dervishes some has white imamah, some has green imamah memory of hajj on their head, some has weird shaped caps, they all have an amber rosary in their hands and they all whimper with constant praises in each step they take (Ibanez,2006)"
\end{abstract}

In this part of the research, Vincento Blasco Ibanez's opinions on Turkish dressing are given under the title of women, men and soldier dressings.

In second half of XIX century, there occurred great changes in the issue of dressing in Ottomans and European style clothes began to be preferred more. The first ones to follow the European fashion in Ottoman Empire were the Muslim women who are member of palace and upper classes. Therefore, the alteration in the cloths started in palace at first and then reflected to the families being in good shape and the public. This change showed itself firstly in the accessories (gloves, socks etc.) and took hold of outer wear in time (Sevin,1973). In this rapid modernization period took place, Ferace (full coats worn by Turkish women) and yashmak models being among the women cloths in the ends of $19^{\text {th }}$ century began to get lost in time and veil and burqa started to take the place of ferace in the period of Abdulhamit II (1876-1909) (Arıg,2007).

"Ottoman Women" comprising an important section of the society became the individuals mostly handled by foreigner itinerants and generally misrepresented. The perception of harem in the minds of western society was reflected quite different from the reality for a long period of time due to the conjectures of men itinerants of $19^{\text {th }}$ century (ilya \&Uysal,2015). The difference between the way of 
Arga Sahinoglu, M. (2016) Opinions of Vicente Blasco Ibanez, one of Travelers of $20^{\text {th }}$ Century about Clothes of Turks (Example of "Orient Before The Storm"), 0 [Online]. 03, pp 149-156. Available from:

http://sproc.org/ojs/index.php/pntsbs

living of Western society and Ottoman society and bias in western culture towards east caused emergence of such a perception. However, in his itinerary, Vicente Blasco Ibanez expressed that Turkish women are not as told in the West and they have a quite European dressing styles.

It is observed that Ibanez presented an opinion concerning burqa, yashmak and veil in women wear. Vicente Blasco Ibanez expressed that traditional dressing is an element leading women into a darkness and rich men in Ottomans ended traditional dressings of their wives and presented and European appearance with these words:

"In fact, big ladies, elegant wives of pashas and rich people living in luxurious harems ended the traditional clothes blacking women out to an unknown darkness under the cover of fashion for a long time. They wear flaming and garish Paris cloths with a vengeance under the coat of east resembling the cloaks worn while going out of theatres. Though they cover their faces in compliant with the order of religious custom, yashmak, which is a transparent veil light as a cloud, serves for a silk breath that cannot be caught and sweeting the face ultimately (Ibanez, 2006)"

The primary accessories integrated with Turkish women are veil or yashmak. Vicente Blasco Ibanez included his opinions mostly on veil and yashmak concerning the dressing of women in this book. Yashmak is a cover comprising of two parts leaving ajar in front of their eyes, one coming from the upper side and other from the lower side and made of thin white cheesecloth which Islamic women hold in front of their faces when they wear ferace in the street (Kocu,1969). Vicente Blasco Ibanez thinks that these yashmaks made with thin cloths sweeten the women and make them attractive and mysterious. Ibanez expresses his views on yashmak and veil by this means:

"Though they cover their faces in compliant with the order of religious custom, yashmak, which is a transparent veil light as a cloud, serves for a silk breath that cannot be caught and sweeting the face ultimately (Ibanez,2006)"

"Under the lights of the sun warming up the woods of Galata bridge, this mysterious and covered masked women bring attraction to the crowd suiting novels (Ibanez,2006)"

"There is a piece of silk acting as a mask in the groove hitting back to face in the head part of burqa; veils of some women are thick and hides the eyes of the person behind it completely, and some other women wear transparent and attractive yashmaks made as if those are made for only decorative purposes (Ibanez,2006)"

While Ibanez thinks that thin yashmak and veil make women attractive and mysterious, he thinks that thick veils are used by woman who are old or get ugly with an illness to cover their faces and states this with the following words.

"The qualification of this mask allows understanding the value of the one who is hiding behind it without seeing her. General rule is that thick veils cover the faces of an old woman or a woman gets ugly by suffering from terrible diseases of the east. A Spanish servant or young priestess face is hidden behind thin veils: double chins, moonlike cheeks reddened with blusher and beautiful eyes made large with black kohl, just like the eyes of cows (Ibanez, 2006)"

At the same time, Ibanez states that veil is a tool for women to protect themselves.

"Turkish Women walk in Pera streets under cover and watch the Europeans pursuing them with hungry eyes under their veils (Ibanez, 2006)"

Ibanez also gave place in his itinerary about burqa. Burqa is the name of one of the street garments of women in the period when Muslim Turkish women must be under cover. It was used as street clothing comprising of three parts at first in İstanbul and then Anatolia and Rumelia. Three parts of 
Arga Sahinoglu, M. (2016) Opinions of Vicente Blasco Ibanez, one of Travelers of $20^{\text {th }}$ Century about Clothes of Turks (Example of "Orient Before The Storm"), $\quad 0$

http://sproc.org/ojs/index.php/pntsbs

[Online]. 03, pp 149-156. Available from:

burqa are: 1 . veil covering the face 2 . Cloak covering the upper part of the body together with head and 3. Skirt covering the part of the body from waist to the feet. Usage in different colors were observed in that period (Kocu,1969). The expressions of ibanez while stating the woman with burqa he saw in the street can be interpreted as he did not like burqa.

"Poor or middle class women are loyal to thick veils acting as a mask with their burqa made of heavy Damascus silk. Therefore, you see them passing as a mysterious carnival mask, pulling a big-headed Turkish kid by hand or an umbrella in the hand and holding rasping skirts by other hand and their thick calves turned into leg of an elephant swollen by putting the legs of salwar into the socks are seen under the skirts (Ibanez,2006)".

"The place of istanbul mostly protecting the spirit of Turk and Muslims. Mosque comes after Mekke in terms of holiness. Old women of the neighborhood wrapped up in black burqas splits at the bottom of all Christians they encounter in the street at nightfall and shout out curses (Ibanez, 2006)".

"More quiet women being the wives of Muslims settled in İstanbul side and bound to traditions or simple public women walk on as wrapped up in black, red, green or dark blue cloths made of heavy silk damask from head to foot. Shirring and sashed arms of the undergarments are seen through the wide arms of burqas. They embrace to umbrella and bags with their hands in gloves (Ibanez, 2006)".

Author presents opinion concerning that Turkish men are always chic and clean while he is mentioning about them. Furthermore, he draws the attention to the fact that men have a quire European appearance. He frequently expresses in his itinerary that redingote worn in Ottoman has a quite chic appearance. The jacket of redingote is a long-skirted European men's costume. It was started to be worn in the period of Abdulhamit II instead of Stambouline and it became old-fashioned after the first years of Republic. Redingotes made of black homespun woolen cloth were accepted as official ceremony cloth for high civil service including civil high state officials and protocol. Its breast is closed by looping two buttons. There are two unused decoration button on the left. Its skirts below the belt flow freely to the bottom of patella. Pants made of the fabric of redingote and jacket is worn and its vest is of white or buff fabric. A Frank shirt breast and collars of which are starched is absolutely worn with redingote. A single nodded necktie is bound and a beautiful breastpin of jewelry work is affixed to necktie (Kocu, 1969). İbanez expresses his opinions on men's wear as in the following:

"It reminds a European gentleman wearing a fez as a nightcap on his head with an exotic enthusiasm. Wears black and an expensive vest made of eastern silk is seen through the collar of redingote. When he crosses his legs, Turkish style top-boots are seen under the legs of pants. It is the only detail that is not compliant with appearance of European (Ibanez, 2006)."

"A set of men in black open a road for themselves in the middle of bridge suddenly in the spirit of softness of a priest, bowing and scraping. Elegant palace redingote worn in ceremonies and closed as cassock, colarless called as stambouline on their back (Ibanez, 2006)."

One of the dressing accessories that draw the attention of the author most is "fez". The opinions of the author on "fez" are stated in several sections of itinerary. Fez is a red colored head wear invested 
Arga Sahinoglu, M. (2016) Opinions of Vicente Blasco Ibanez, one of Travelers of $20^{\text {th }}$ Century about Clothes of Turks (Example of "Orient Before The Storm"), $O$

http://sproc.org/ojs/index.php/pntsbs

[Online]. 03, pp 149-156. Available from:

in the city of Morocco in the west of Northern Africa (Kocu,1969). Fez is a piece of cloth having a high symbolic power within dressing reforms. Arranged as official costume of soldiers and of officers a year after by Mahmut II, fez became the symbol of reforms. It became a proper accessory of dark colored jacket with its simplicity and attractive red color. Spread to wide social layers within a short period of time and started to be perceived as a symbol of Ottoman traditionalism. Brought from Northern Africa, fez remained as traditional, old and national cap in ottoman Turks (Ucar, 2013)

Vicente Blasco Ibanez characterized "fez" as an identity showing the nationality of Turkish men. Moreover, he put the express on the fact that fez is an accessory completing the costumes of Europeans. Vicente Blasco Ibanez draws the attention to that the fez placed on head when wake up in the morning is not removed throughout the day and opening the head is a great impoliteness.

"Thousands of fez swing while walking also completes the costumes of Europeans as well as fast costumes of Turks (Ibanez, 2006)".

"A young Turkish man lives close to me, he wears European style chic dressed, cone collar, garish necktie, stripe English jacket. The only thing informing against his nation is fez (Ibanez, 2006)".

It is observed that Ibanez mentioned about the costumes of soldiers in many sections of his itinerary. The costume of the army called as "Asakir-i Mansure-i Muhammediye" founded in European style instead of the Guild of Janissaries abolished in 1826 in Ottomans, are arranged as jacket, pants, fez and half boot in European style. In "Regulation on Military Costumes" entered into force in 1909 by being published, fez was used as official cap until the alteration is made in the dressings of officers and soldiers (Aysal, 2011). Vicente Blasco Ibanez draws the attention to the fact that military costumes used in this period have a European appearance.

"Here, we are in Ottoman Empire. In the station of Edirne, being the most important city coming after İstanbul; second capital city of European side of Turkey. Platforms are full of officers wearing simple and chic uniforms similar to Germans but all have unchanging fez on their heads (Ibanez, 2006)".

"Ottoman mariners wear fez on the uniforms being the same as all navies of the entire world and this is an exotic detail added to the appearance of European mariner appearance. And also the officers with English style medals, swords on their seats, with white gloves and patent leather shoes wander around with fez on their heads (Ibanez, 2006)".

"Turkish military troops present a serious and earnest appearance. The only colorful part of the dark colored uniforms is their arm cuffs and vivid red of the fez (Ibanez, 2006)".

Ibanez participated in the rites of Mevlevi Dervishes and described a Turkish officer came to there and again the chicness of Turkish men.

"A new viewer of the rite sits next to me. An officer of Turkish army, a young sublieutenant, the only different part of his uniform in English style is the red fez on his head. Laces of the arm cuffs ended in oval shape are sparkling on the dark blue fabric of redingote. Attached with a huge pearl, knot of his tie draws the attention between his neckband in spotless white reflecting the close objects as a mirror and white breast of his shirt. He carries his patent leather shoes on the hand and his feet step on the mat of the ground (Ibanez, 2006)". 
Arga Sahinoglu, M. (2016) Opinions of Vicente Blasco Ibanez, one of Travelers of $20^{\text {th }}$ Century about Clothes of Turks (Example of "Orient Before The Storm"), 0

http://sproc.org/ojs/index.php/pntsbs

[Online]. 03, pp 149-156. Available from:

\section{Conclusion}

In this research, the itinerary of Vicente Blasco Ibanez, one of the itinerants of XX. century, called as Orient Before Storm were analyzed and his opinions on the clothing of that period were tried to be determined.

Traveler may give place to comparisons for readers' perceive what traveler saw more clearly. Thus, readers are like they are wandering these places together with the author. Itineraries frequently applied in the studies related to the image of Turks are significant elements in the generation of the image. Spanish Vicente Blasco Ibanez's stating in his expressions that he changed his mind against Turks is an indicator of that the image of Turks gained new meaning for Europeans. In this sense, the image of Turks and status of Turkish dressings in the work of Vicente Blasco Ibanez gained an importance (Kırca, 2010).

Spanish politician and man of letters, Vicente Blasco Ibanez came to İstanbul in 1907 and learnt that Turks are different from the images of the Europeans through experience. In "Orient Before Storm İstanbul 1907", he told the life styles of Turks and created a real Turkish image for Europe (Tozoglu, 2010).

It is observed in the itinerary of Vicente Blasco Ibanez that he made interpretations on the costumes of woman, man and soldiers. Furthermore, he also made some descriptions regarding the dressing of whirling dervishes.

As a result of the research carried out, it attracted the notice that Vicente Blasco Ibanez constantly made comparisons between the wear of Turkish man and woman and the Europeans. In this respect, he expresses that the costumes of rich Turkish women are as Europeans. He thinks that traditional women dressing push the women into darkness. Also, he considers that thin yashmak and veils used by women make them sweeten and attractive.

It is understood while he is mentioning about the wear of Turkish men that the most attractive thing for him is fez. He states that men have European appearance and fez complete this European appearance. Moreover, he sees fez a kind of national identity. He also draws the attention to the fact that men are always clean and chic while he is mentioning about them. Again, he put emphasize on the fact that redingote used by men is elegant and chic.

Vicente Blasco Ibanez said several things apart from the general Turkish image in Europe by stating that "all authors coming to Turkey feel indignation against the injustice deemed suitable of this nation. Turk is good and open hearted. Turk is the most religious among people. It is impossible to tarnish his faith. Poor Turkey! The more I am closely acquaintance with it, the more I love it, because I appreciate its virtues and see the dangers threatening it more obviously." (Onalp, 2008). When the results of the research are looked at, it is observed that Vicente Blasco Ibanez states that the things told in Europe about the dressing of Turks are not true.

\section{References}

Akkanat, C. (2008-2009). Seyahatnameler

Akman, F. B. (2011).

Ozel Sayisi,

15.

Arıg, A. S. (2007).

Istanbul: Etkilesim Yayinlari.

Aysal, N. (2011). Tanzimat'tan Cumhuriyet'e giyim ve kusamda cagdaslasma hareketleri. $\quad$, X/22, Bahar, ss.332. Received from: July 03, from http://web.deu.edu.tr/ataturkilkeleri/ai/uploaded files/file/dergi 22 new/01 \%20Necdet\%20Aysal.pdf

Best, O. (1982). Handbuch literarischer fachbegriffe, Frankfurt a.M.

Ibanez, V. B. (2007).

. İstanbul: Turkiye is Bankası Kultur Yayinlari. 
Arga Sahinoglu, M. (2016) Opinions of Vicente Blasco Ibanez, one of Travelers of $20^{\text {th }}$ Century about Clothes of Turks (Example of "Orient Before The Storm"), 0 [Online]. 03, pp 149-156. Available from: http://sproc.org/ojs/index.php/pntsbs

ilya, D., \& Uysal, M. (2015). İngiliz kadın seyyahlar Harvey ve Garnett'in gozuyle osmanlı kadını. $X \quad$ 3(6), Received July 03, 2015 from: http://avrasyad.com/Makaleler/375394548 1577263539 6.\%20SAYl\%20Ss.\%201-22.pdf

Donmez, i. H. (2013). Yerli ve batılı iki seyyahın gozuyle osmanlı kadını: karsılastırmalı bir analiz.

(5), 93-105.

Gokyay, O. S. (1973). Turkce'de gezi kitapları.

457-467.

Kırcl, H.S. (2010)

. Suleyman Demirel Universitesi Sosyal Bilimler Enstitusu Bati Dilleri ve Edebiyatı Ana Bilim Dalı, Yuksek Lisans Tezi.

Kocu , R. E. (1996) . İstanbul: Guncel Yayincilik.

Maden, S. (2008) Turk edebiyatinda seyahatnameler ve gezi yazıları. $X$ , Sayı 37, Erzurum, 147-158.

Mumcu, A. (1987). Almanca yazilmis seyahatnameler ve bu ture giren eserlerin tanitimi konusunda konusma. $x$ No:221, Eskisehir:Egitim Fakultesi Yayınları No:6.

Onalp, E. (2008). Ispanyol roman yazarı Vicente Blasco Ibanez'de Turk imajı, Yayınevi, 259-266.

Sevin, N. (1973).

. Istanbul: Basbakanlık Kultur Mustesarligi Kultur Yayinlari

Tozoglu, E. (2010).

Kulturel Temelleri

. Ankara Universitesi Egitim Bilimleri Enstitusu, Egitim Bilimleri Anabilim Dalı, Egitimin 